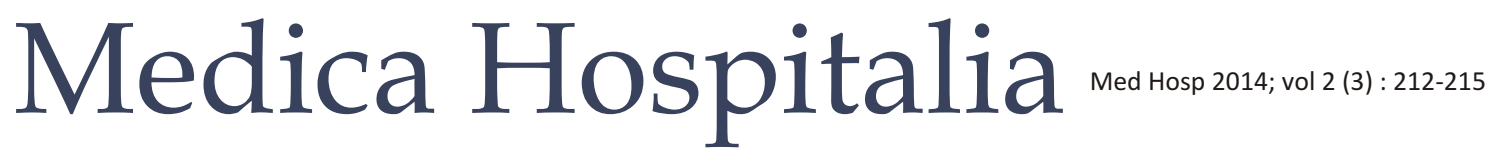

Case Report

\section{Persalinan Sungsang di RSUP Dr. Kariadi Semarang}

\author{
Yulice Soraya Nur Intan, Besari Adi Pramono \\ Divisi Fetomaternal, Bagian Obstetri dan Ginekologi, \\ Fakultas Kedokteran Universitas Diponegoro, RSUP Dr. Kariadi, Semarang
}

\begin{abstract}
Abstrak
Tujuan : Mendapatkan gambaran luaran persalinan sungsang di RSUP Dr. Kariadi Semarang tahun 2013.

Metode : Penelitian deskriptif retrospektif dan analytical work, pada 283 kehamilan dengan letak sungsang yang melahirkan di RSUP Dr. Kariadi Semarang di tahun 2013, dibagi menjadi persalinan pervaginam 129 subyek dan bedah sesar 154 subyek. Data diambil dari rekam medik pasien yang meliputi usia, pendidikan, pekerjaan, pembiayaan, usia kehamilan, paritas, hemoglobin $(\mathrm{Hb})$, riwayat ANC, status dan asal rujukan, jenis persalinan, penolong persalinan, tempat persalinan, ketuban pecah dini, mortalitas neonatus, mortalitas dan morbiditas maternal.

Hasil : Persalinan sungsang pervaginam memiliki risiko 5,16 kali lebih besar terjadi perdarahan post partum dan 5,32 kali lebih besar skor apgar menit ke-5 kurang dari tujuh dibanding persalinan sungsang bedah sesar. Persalinan sungsang pervaginam memiliki risiko kematian neonatus dini 3,85 kali lebih besar ketimbang persalinan sungsang bedah sesar $(p=0,015$; $\mathrm{OR}=3,85$; IK 95\% 1,21-12,23). Nulipara memiliki resiko 8,15 kali lebih besar terjadi kematian neonatal dini dibanding multipara.

Simpulan : Persalinan sungsang pervaginam memiliki risiko lebih besar dibandingkan bedah sesar. Bedah sesar menawarkan hasil luaran yang lebih baik dibanding pervaginam dalam hal perdarahan post partum sementara kejadian asfiksia dan kematian neonatus dini tidak dipengaruhi oleh jenis persalinan.
\end{abstract}

Kata kunci : Persalinan sungsang, luaran maternal, Luaran neonatus

\section{Breech deliveries in Kariadi Hospital Semarang}

\begin{abstract}
Objective : Get an overview of breech delivery's outcomes in Kariadi Hospital Semarang in 2013.

Methods : A retrospective descriptive study with analytical work, the subjects were 283 pregnant women with breech who gave birth in Kariadi Hospital in 2013, divided into vaginal delivery groups of 129 subjects and cesarean section group of 154 subjects. The data taken from medical records that include age, education, employment, finance, gestational age, parity, hemoglobin $(\mathrm{Hb})$, antenatal care, referralstatus, referral source, type of delivery, birth attendants, place of delivery, premature rupture of membrane, neonatal mortality, maternal mortality and morbidity. Results : Breech vaginal delivery group had 5.16 times greater risk of postpartum bleeding and had 5.32 times greater risk Apgar score 5 th minute less than seven than caesarean section. Vaginal breech deliveries had risk of early neonatal mortality 3.85 times greater than the breech cesarean section ( $p=0.015 ; \mathrm{OR}=3.85 ; 95 \%$ $\mathrm{Cl} 1.21-12.23)$. Nulliparous had 8.15 times greater risk of early neonatal death than multiparous.

Conclusion : Vaginal delivery had a greater risk compared with cesarean section. Cesarean section offers a better outcome than vaginally in terms of postpartum bleeding, while asphyxia and early neonatal mortality was not affected by the type of delivery.
\end{abstract}

Keywords : Breech deliveries, maternal outcomes, Neonatal Outcomes

\section{PENDAHULUAN}

Angka kematian ibu dan bayi pada letak sungsang lebih tinggi dibanding persalinan yang lainnya. Kejadiannya $4 \%$ di seluruh Indonesia. ${ }^{1-3}$ Royal College of Obstetricians and Gynaecologists (RCOG) dan American Congress of Obstetricians and Gynecologists (ACOG) tahun 2001 merekomendasikan bahwa metode persalinan yang baik untuk janin tunggal aterm dengan presentasi bokong murni atau presentasi bokong kaki sempurna adalah bedah sesar elektif. ${ }^{4-6}$ Angka persalinan sungsang di RSUP Dr. Kariadi Semarang cukup tinggi bila dibandingkan dengan angka kejadian sungsang di Indonesia, namun luaran maternal dan neonatal beserta faktor yang mempengaruhi belum pernah diteliti di RSUP Dr. Kariadi Semarang. 


\section{METODE}

Penelitian ini merupakan penelitian deskriptif retrospektif dengan analytical work ini mengambil subyek 283 persalinan sungsang di RSUP Dr. Kariadi tahun 2013. Data meliputi usia, pendidikan, pekerjaan, pembiayaan, usia kehamilan, paritas, kadar hemoglobin $(\mathrm{Hb})$, riwayat ANC, asal rujukan, jenis, penolong dan tempat persalinan, ketuban pecah dini, serta mortalitas neonatus. Analisis data dilakukan untuk melihat perbedaan distribusi data morbiditas, mortalitas maternal dan neonatal antara kelompok persalinan presentasi sungsang pervaginam dan bedah sesar

\section{HASIL}

\section{KARAKTERISTIK SUBYEK PENELITIAN}

Karakteristik subyek penelitian ditampilkan pada tabel 1. Hasil uji statistik perbedaan variabel umur, umur kehamilan, tingkat pendidikan, pekerjaan dan pembiayaan antara kelompok persalinan pervaginam dan bedah sesar adalah tidak bermakna, namun didapatkan perbedaan yang bermakna pada variabel paritas dan kadar $\mathrm{Hb}$ antara kelompok persalinan pervaginam dan bedah sesar, dimana multigravida pada kelompok pervaginam $(68,2 \%)$ lebih banyak dibanding kelompok bedah sesar, dan primigravida pada kelompok

\begin{tabular}{|c|c|c|c|}
\hline \multirow[t]{2}{*}{ Karakteristik } & \multicolumn{2}{|c|}{ Jenis persalinan } & \multirow[t]{2}{*}{$p$} \\
\hline & $\begin{array}{l}\text { Pervaginam } \\
(n=129)\end{array}$ & $\begin{array}{c}\text { Bedah sesar } \\
\quad(n=154)\end{array}$ & \\
\hline Umur (tahun) & $29,1 \pm 5,09$ & $28,9 \pm 4,80$ & $0,9 ¥$ \\
\hline \multicolumn{4}{|c|}{ Umur kehamilan (minggu) $n(\%)$} \\
\hline Preterm & $18(14,0)$ & $18(11,7)$ & $0,4^{*}$ \\
\hline Aterm & $109(84,5)$ & $130(84,4)$ & \\
\hline Postterm & $2(1,6)$ & $6(3,9)$ & \\
\hline \multicolumn{4}{|l|}{ Paritas; n (\%) } \\
\hline Primigravida & $41(31,8)$ & $73(47,4)$ & $0,008^{*}$ \\
\hline Multigravida & $88(68,2)$ & $81(52,6)$ & \\
\hline Kadar Hb (g/dL) & $11,7 \pm 1,39$ & $12,2 \pm 1,22$ & $0,004 ¥$ \\
\hline \multicolumn{4}{|l|}{ Pendidikan; n (\%) } \\
\hline SD & $15(11,6)$ & $25(16,3)$ & $0,3^{*}$ \\
\hline SMP & $40(31,0)$ & $34(22,2)$ & \\
\hline SMA & $69(53,5)$ & $85(55,6)$ & \\
\hline Sarjana & $5(3,9)$ & $9(5,9)$ & \\
\hline \multicolumn{4}{|l|}{ Pekerjaan; n (\%) } \\
\hline Ibu rumah tangga & $98(76,0)$ & $112(72,7)$ & $0,7^{*}$ \\
\hline PNS & $3(2,3)$ & $1(0,6)$ & \\
\hline Pegawai swasta & $13(10,1)$ & $21(13,6)$ & \\
\hline Wiraswasta & $10(7,8)$ & $13(8,4)$ & \\
\hline Lainnya & $5(3,9)$ & $7(4,5)$ & \\
\hline \multicolumn{4}{|l|}{ Pembiayaan; n (\%) } \\
\hline Umum & $14(10,9)$ & $28(18,2)$ & $0,2^{*}$ \\
\hline Jampersal & $70(54,3)$ & $94(61,0)$ & \\
\hline Lainnya & $45(34,9)$ & $32(20,8)$ & \\
\hline
\end{tabular}

$* \mathrm{Uji} \mathrm{x}^{2}$

$¥$ Uji Mann-Whitney

Persentase dihitung berdasarkan kolom

$\S$ Rerata \pm Simpang baku; median (min-maks) 


\section{TABEL 2}

Karakteristik neonatus pada persalinan sungsang secara pervaginam dan bedah sesar

\section{Karakteristik}

Jenis persalinan

\section{Pervaginam \\ $(n=129)$}

Jenis kelamin; $(\mathrm{n} \%)$
$72(55,8)$

$57(44,2)$

$2881,9 \pm 455,03$

$4(3,1)$

$125(96,9)$

$13(10,1)$

$3(2,3)$

$113(87,6)$

$117(90,7)$

$12(9,3)$

Meninggal

$$
84(54,5)
$$

$3040,3 \pm 298,24$

$8(5,2)$

0,4 *

$146(94,8)$

$2(1,3)$

$0,002 *$

$1(0,7)$

$150(98,0)$

$150(97,4)$

$0,015 *$

$0,8^{*}$

$0,004^{¥}$

.

p

$4(2,6)$

*Uji $X^{2}, ¥$ Uji Mann-Whitney, Persentase dihitung berdasarkan kolom, § Rerata \pm Simpang baku; median (min-maks)

\section{TABEE 3}

Mortalitas dan morbiditas maternal pada persalinan sungsang secara pervaginam dan bedah sesar

Karakteristik
Jenis persalinan

$$
\begin{aligned}
& \text { Pervaginam } \\
& (\mathrm{n}=129)
\end{aligned}
$$

$\boldsymbol{p}$

Bedah sesar $(n=154)$

Status ibu pasca persalinan; $\mathrm{n}(\%)$

$\begin{array}{lcc}\text { Hidup } & 129(100) & 154(100) \\ \text { Meninggal } & 0(0,0) & 0(0,0)\end{array}$

Perdarahan post partum

Ada $12(9,3)$

Tidak ada

$117(90,7)$

$3(1,9)$

$0,006^{*}$

Lama rawat inap (hari)

$151(98,1)$

$3,9 \pm 0,90$

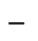

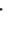

*Uji $X^{2}, ¥$ Uji Mann-Whitney, Persentase dihitung berdasarkan kolom, § Rerata \pm Simpang baku; median (min-maks)

bedah sesar $(47,4 \%)$ lebih banyak dibanding kelompok pervaginam. Sedangkan kadar $\mathrm{Hb}$ pada kelompok pervaginam $(11,7 \pm 1,39 \mathrm{~g} / \mathrm{dL})$ lebih rendah dibanding kelompok bedah sesar.

Hasil uji statistik perbedaan variabel jenis kelamin bayi dan status lilitan tali pusat antara kelompok persalinan pervaginam dan bedah sesar adalah tidak bermakna, namun didapatkan perbedaan yang bermakna pada variabel berat badan lahir, skor apgar menit ke-5 dan mortalitas neonatus, dimana rerata berat badan lahir bayi pada kelompok pervaginam
(2881,9 $\pm 455,03$ gram) lebih ringan dibanding kelompok bedah sesar. Skor apgar 7-10 pada kelompok bedah sesar (98\%)lebih tinggi dibanding kelompok bedah sesar, sedangkan skor Apgar 0-3 lebih banyak dijumpai pada kelompok pervaginam $(10,1 \%)$ dibanding kelompok bedah sesar. Kematian neonatus dini lebih besar pada kelompok persalinan pervaginam $(9,3 \%)$ dibandingkan dengan persalinan bedah sesar.

Mortalitas dan morbiditas maternal pada persalinan sungsang secara pervaginam dan bedah sesar ditampilkan pada tabel 4, dimana kejadian perdarahan 
post partum lebih banyak pada kelompok pervaginam $(9,3 \%)$ dibanding kelompok bedah sesar secara bermakna $(p=0,006)$, dan rerata lama rawat inap pada kelompok pervaginam $(3,0 \pm 1,35$ hari) lebih singkat dibanding pada kelompok bedah sesar.

\section{PEMBAHASAN}

Selama tahun 2013 terdapat 283 kasus persalinan sungsang yaitu sebesar 8,86\% dari 3.192 persalinan yang ada di RSUP Dr. Kariadi Semarang. Angka ini lebih tinggi bila dibandingkan dengan angka kejadian letak sungsang di Indonesia yang dapat mencapai $4 \%{ }^{3}$ Sebagian besar persalinan sungsang di RSUP Dr Kariadi Semarang melalui bedah sesar dengan indikasi terbesar presentasi kaki. ${ }^{7}$ Perdarahan post partum adalah risiko terbesar pada persalinan letak sungsang.8-12

Keberhasilan persalinan letak sungsang berkaitan dengan jumlah air ketuban. Risiko morbiditas pada ibu dan bayi meningkat dengan adanya ketuban pecah dini pada persalinan sungsang, sehingga persalinan lewat bedah sesar lebih dipilih pada ibu hamil sungsang dengan ketuban pecah dini. Hal ini sesuai pada penelitian kami dimana proporsi persalinan dengan bedah sesar dengan ketuban pecah dini lebih tinggi dibanding persalinan pervaginam.

Luaran neonatal buruk lebih banyak secara bermakna pada persalinan sungsang pervaginam. ${ }^{13}$ Risiko kematian perinatal untuk janin aterm dengan presentasi bokong murni atau presentasi bokong kaki sempurna akan berkurang sebesar 75\% dengan dilakukannya bedah sesar elektif. ${ }^{5}$ Pada penelitian ini didapatkan kematian neonatus dini pada persalinan sungsang pervaginam lebih besar daripada persalinan bedah sesar dimana persalinan sungsang pervaginam memiliki resiko kematian neonatal dini lebih besar dibanding persalinan dengan bedah sesar.

Analisis multivariat menunjukkan ketuban pecah dini lebih mempengaruhi kejadian asfiksia neonatus dan jenis persalinan tidak berpengaruh pada kejadian asfiksia neonatus. Agar skor menit kelima yang lebih rendah pada kelompok persalinan pervaginam mungkin disebabkan karena proses persalinan kala II, setelah bokong crowning kompresi tali pusat oleh bagian janin dan kepala yang mulai masuk panggul akan menyebabkan asidosis respiratorik pada janin. Disamping itu penggunaan agen sedasi yang biasa dilakukan menyebabkan ibu tidak dapat mengejan dengan baik, sehingga menyebabkan keterlambatan pengeluaran bayi pada fase cepat. ${ }^{14}$

\section{SIMPULAN}

Kelompok persalinan pervaginam memiliki resiko lebih besar terjadi perdarahan post partum dibandingkan dengan kelompok bedah sesar.Kejadian afiksia neonatus lebih dipengaruhi oleh faktor ketuban pecah dini dan kadar $\mathrm{Hb}$ sebelum persalinan. Kematian neonatus dini lebih dipengaruhi oleh faktor paritas dan kadar $\mathrm{Hb}$ sebelum persalinan. Bedah sesar menawarkan hasil luaran yang lebih baik dibanding pervaginam dalam hal perdarahan post partum sementara kejadian asfiksia dan kematian neonatus dini tidak dipengaruhi oleh jenis persalinan.

\section{DAFTAR PUSTAKA}

1. Cunningham F, Leveno K, Bloom S, Hauth J, Rouse D, Spong C. Williams Obstetrics: 23rd Edition. New York: McGraw-Hill Education, 2009.

2. Gimovsky ML. Breech Presentation. In: O'Grady JP, Gimovsky ML, editors. Operative Obstetrics. 2nd Edition. New York: Cambridge University Press, 2008:pp. 297-321.

3. Wiknjosastro H. Ilmu kebidanan Edisi Ketiga. Jakarta: Yayasan Bina Pustaka Sarwono Prawirohardjo, 2002.

4. Turner MJ. The Term Breech Trial: are the clinical guidelines justified by the evidence? J Obstet Gynaecol 2006;26:491-4.

5. Hannah ME, Hannah WJ, Hewson SA, Hodnett ED, Saigal S, Willan AR. Planned caesarean section versus planned vaginal birth for breech presentation at term: a randomised multicentre trial. Term Breech Trial Collaborative Group. Lancet 2000;356:1375-83.

6. Alarab M, Regan C, O'Connell MP, Keane DP, O'Herlihy C, Foley ME. Singleton vaginal breech delivery at term: still a safe option. Obstet Gynecol 2004;103:407-12.

7. Goffinet F, Carayol M, Foidart JM, Alexander S, Uzan S, Subtil $\mathrm{D}$, et al. Is planned vaginal delivery for breech presentation at term still an option? Results of an observational prospective survey in France and Belgium. Am J Obstet Gynecol 2006;194:1002-11.

8. Kumari AS, Grundsell H. Mode of delivery for breech presentation in grandmultiparous women. Int J Gynaecol Obstet 2004;85:234-9.

9. Doyle NM, Riggs JW, Ramin SM, Sosa MA, Gilstrap LC, 3rd. Outcomes of term vaginal breech delivery. Am J Perinatol 2005;22:325-8.

10. Golfier F, Vaudoyer F, Ecochard R, Champion F, Audra P, Raudrant D. Planned vaginal delivery versus elective caesarean section in singleton term breech presentation: a study of 1116 cases. Eur J Obstet Gynecol Reprod Biol 2001;98:186-92.

11. Herbst A, Thorngren-Jerneck K. Mode of delivery in breech presentation at term: increased neonatal morbidity with vaginal delivery. Acta Obstet Gynecol Scand 2001;80:731-7.

12. Shiliang L, M LR, K. SJ, Maureen H, Reg S, S KM. Maternal mortality and severe morbidity associated with low risk planned cesarean delivery versus planned vaginal delivery at term. Canadian Mediacal Association Journal 2007;176:455-460.

13. Pradhan P, Mohajer M, Deshpande S. Outcome of term breech births: 10-year experience at a district general hospital. BJOG 2005;112:218-22.

14. SOGC. Vaginal Delivery of Breech Presentation. Canada: JOGC, 2009:557-566. 